\title{
Antimicrobial Activity of Some Trichoderma spp. against Different Kinds of Fungal and Bacterial Isolates
}

\author{
Omar Mu'ayad Al-Obaidy \\ Department of Biology \\ College of Science \\ Mosul University
}

\author{
Received \\ Accepted \\ 12/11/2013 \\ 05/03/2014
}

الفعالية الضد ميكروبية لبعض أنواع . Trichoderma spp. ضد أنواع مختلفة من العزلات الفطرية والبكتيرية لونية لونية



تم اختبار نوعين من فطر Trichoderma وهما T.viride و T.harzianum وتم اختبار فعاليتهما ضد أنواع عديدة من الفطريات الممرضة للنبات والإنسان وبعد الغربلة تم انتخاب الفطر T.harzianum الذي اظهر كفاءة أعلى في فعاليه التضادية من الفطر T.viride والإنسان وكان الفطر Macrophomina phaseolina الاكثر تحسسا تجاه الفطر T.harzianum فعاليتها ضد أنواع مختلفة من الفطريات الممرضة و ضد أنواع مختلفة من البكتريا المرضية السالبة والموجبة لصبغة كرام حيث أظهرت قيم مختلفة من الفعالية التثبيطية وكانت البكتريا Bacillus subtilis للتأكد من سلامة الفطر (وكنللك مستخلصه) وعدم سميته وفعاليته المضادة للأحياء المجرية المدروسة داخل الجسم الحي (In-Vivo) وبعدها يمكن استخدامه كبديل عن وسائل المعالجة الكيميائية التي لها آثار جانبية. 


\section{ABSTRACT}

Two types of the fungus Trichoderma were chosen, these are T.viride and T.harzianum. The activity of these fungi were tested against different kinds of plant and human pathogenic fungi. After screening, the fungus T.harzianum was selected because it showed highest efficiency in its antagonistic activity than T.viride. It was also tested against other kinds of the plant and human pathogenic fungi and the fungus Macrophomina phaseolina was the most sensitive toward T.harzianum. In addition, the active compound from the fungus T.harzianum was extracted then tested against different types of pathogenic fungi and different types of pathogenic Gram positive and negative bacteria which showed different values of antagonistic activity. Bacillus subtilis was the most sensitive to the extract. Thus, many tests could be done to ensure the safety of this fungus (and its extract) and that is not toxic and to ensure its antagonistic activity toward the studied microbes inside the living body (In-Vivo), and then it could be used as good alternative to the chemicals that have side effects.

\section{INTRODUCTION}

Biological control agents to fight plant pathogens become more and more widespread. Several mycoparasitic Trichoderma species are used in biocontrol against plant pathogenic fungi such as Botrytis cinerea and Fusarium spp. [1,2). The mechanisms involved in biological control of plant pathogen by Trichoderma are complex and include competition for nutrients and root exudates, inactivation of pathogen's enzymes, direct attack and lysis of the plant pathogen (mycoparasitism), induction of systemic resistance in plants [3, 4] and the production of antibiotic secondary metabolites[5,6]. Mycoparasitic interaction of Trichoderma with the pathogen starts with sensing of the pathogenic fungus. This usually involves the binding of pathogen-derived elicitors, e.g. cell wall degradation products, proteins or toxins against receptor proteins of Trichoderma (membrane or cytosolic proteins) and is followed by signal transduction and response pathways (e.g. secretion of lytic enzymes and antifungal secondary metabolites).

As antifungal secondary metabolites are known to be important for successful biocontrol $[7,8]$. The study aimed to test the antimicrobial activity of different species of the fungus Trichoderma (including T.viride and T.harzianum) that are known to be used as biocontrol agents. The most efficient one was selected and tested for its effect against different types of plant and human pathogenic fungi. Also the active compound was prepared from T. harzianum and its antagonistic or killing 
activity against different types of pathogenic fungi and bacteria were examined.

\section{MATERIALS AND METHODS \\ Microbial strains :}

a) Trichoderma harzianum and Trichoderma viride were used as biocontrol agents for the antagonistic activity study. They were taken from the Plant Protection Department/College of Agriculture/Mosul University.

b) The plant pathogenic fungi Alternaria alternata, Fusarium graminearum, Rhizoctonia solani , and the human pathogenic fungi Aspergillus niger, Trichophyton mentagrophytes, and Candida albicans were taken from Biology Department/ College of Science/ Mosul University, while the fungus Macrophomina phaseolina was taken from Plant Protection Department/College of Agriculture/ Mosul University.

c) The bacterial isolates Staphylococcus aureus, Bacillus subtilis, Streptococcus pyogens, Klebsiella pneumonia, Pseudomonas aeruoginosa, E.coli, Salmonella typhimurium... were taken from Biology Department/ College of Science/ Mosul University.

\section{Antifungal bioassay test (Dual culture tests):}

Interactions between antagonistic fungi and pathogenic fungi were determined by the method described by [9 and 10]. Mycelial disks $(7 \mathrm{~mm}$ in diameter) of pathogenic fungi were placed on one edge of a petri dish containing potato dextrose agar (PDA) or Sabroud agar in the case of human pathogenic fungi, while mycelia disks of Trichoderma spp. (T.harzianum and T.viride) were placed on the opposite side of the plate. After incubation for 7 days, at $28^{\circ} \mathrm{C}$, the overgrowth of colonies of the test fungi by the antagonist was determined.

\section{Production and extraction of the antifungal compound(s) from Trichoderma spp.}

A water-soluble component(s) was extracted with butanol from the culture filtrates of $T$. viride and T.harzianum grown for 14 days[11,12]. Pooled culture filtrate $(50 \mathrm{ml})$ was clarified through Whatman no. 3 filter paper and extracted 2 times with $50 \mathrm{ml}$ of butanol. The butanol extract $(100 \mathrm{ml})$ were pooled dried in a water bath (22 liters Genlab limited) at $60^{\circ} \mathrm{C}$ for 7 to $8 \mathrm{~h}$ each day for three successive days.

To determine the biological activity of the butanol extracts against different pathogenic fungi, the residues were dissolved each in $10 \mathrm{ml}$ of sterile distilled water and from these solutions, $1 \mathrm{ml}$ portion of each of the 
Trichoderma species crude extracts $(100 \%)$ were pipetted into different wells ( $8 \mathrm{~mm}$ diameter) done on the surface of solidified PDA plates at $\mathrm{pH}$ 6 , previously prepared to allow excess water evaporation. Also the Trichoderma species crude extracts were tested against different bacterial isolates (such as Bacillus subtlilis, E.coli, Staphylococcus aureus, Salmonella typhimuriun etc...) in which wells were made on the nutrient agar, then medium was inoculated with the test bacteria, then wells were filled with the fungal extracts and the plates were incubated at $28-30^{\circ} \mathrm{C}$ for 24 hour [13and 14].

\section{RESULTS AND DISCUSSION \\ Antifungal bioassay test}

The two species of the fungus Trichoderma (T.harzianum and T.viride) that are well known for their biocontrol (especially antifungal) activities were at first tested against two pathogenic fungi (Alternaria alternata and Macrophomina phaseolina) to determine and select the most efficient (species) of the fungus Trichoderma and complete testing its effect on other different pathogenic fungi and bacteria. Then to extract and test the active compound(s) from that fungal isolate and to test its biological control activity against different kinds of pathogenic fungi and bacteria. The results showed that the fungus Trichoderma harzianum was better than Trichoderma viride on preliminary test Alternaria alternata and Macrophomina phaseolina in which T.harzianum inhibited the growth by $75 \%$ and $90 \%$ for the fungus Alternaria alternata and Macrophomina phaseolina respectively (figure 1) (when the two fungi were cultured together on the same plate using dual culture technique), while the fungus T.viride inhibited the growth by $60 \%$ and $70 \%$ for A.alternata and M.phaseolina respectively, so the fungus T.harzianum was selected because of its highest inhibitory effect on the selected fungi, to complete testing its activity against other different pathogenic fungi and bacteria. The fungus T.harzianum inhibitied the growth by $70 \%$, $65 \%, 58 \%, 61 \%$, and $0 \%$ for the fungi Fusarium graminearum, Rhizoctonia solani, Aspergillus niger, Trichophyton mentagrophytes, and Candida albicans respectively.

As many researches indicated $[15,16,17,18]$ that for successful biocontrol of T.harzianum on plant pathogenic fungi, Trichoderma at first produce cell degredation proteins or toxins followed by the secretion of lytic enzymes and antifungal secondary metabolites, and the inhibition was due to the production of hydrolytic enzymes or other antifungal compound(s) that hydrolyze and inhibit the growth of the test fungi. 

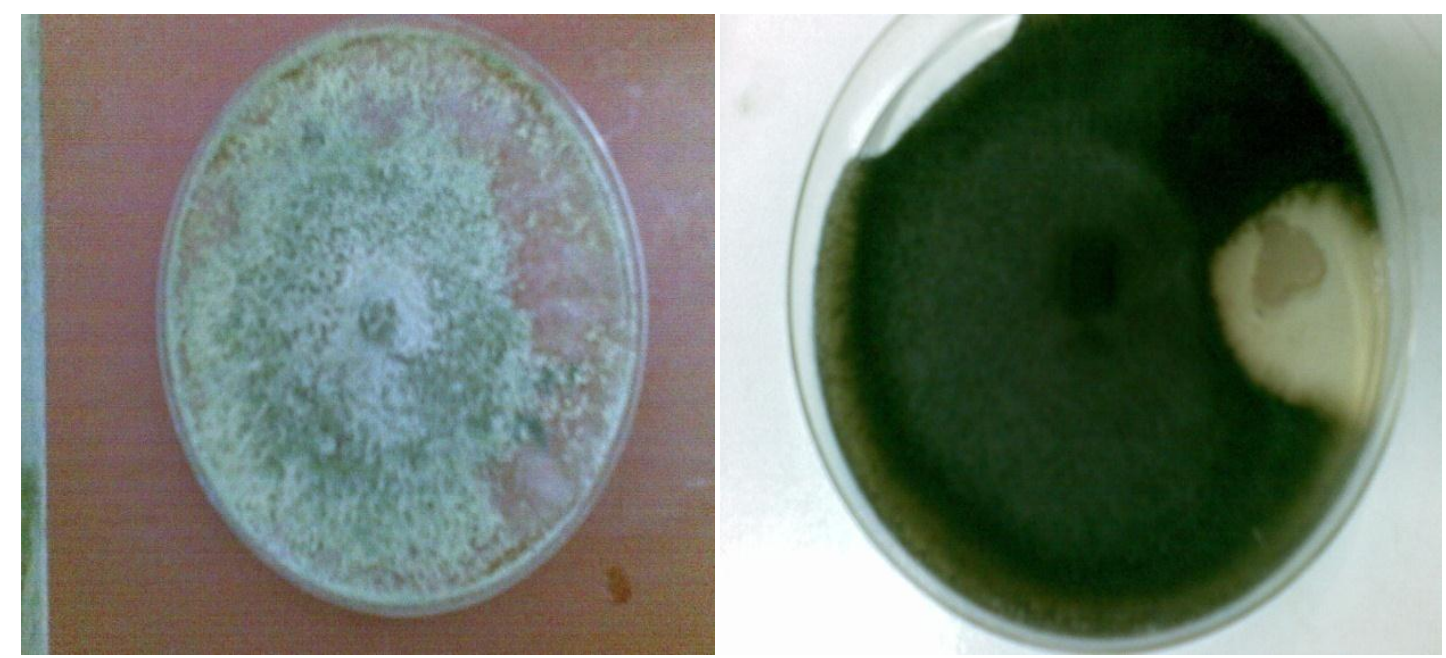

a)

b)

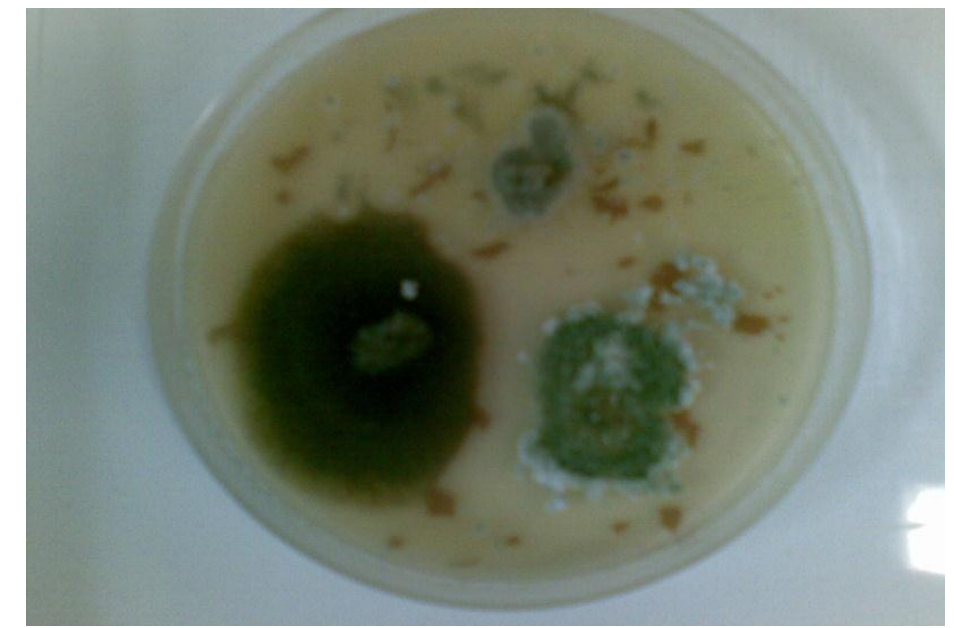

c)

Figure (1) : a) Growth control of Trichoderma harzianum. b) growth control of Alternaria alternata. c) Atagonistic interaction of T. harzianum with Alternaria alternata (left of plate) and Macrophomina phaseolina (top of plate).

Production and extraction of antifungal compound(s) from T.harzianum

Depending on the methods described by [14 and 19], the effect of the crude extract of the fungus $T$. harzianum against different kinds of pathogenic fungi was shown in (table 1) and against different kinds pathogenic bacteria was shown in (table 2 and figure 2). 
Table (1) : Crude extract effect of T.harzianum on different pathogenic fungi

\begin{tabular}{|c|c|}
\hline Test fungi & $\begin{array}{c}\text { Crude extract inhibition zone on } \\
\text { test fungi (mm.) }\end{array}$ \\
\hline Alternaria alternata & 9 \\
\hline Macrophomina phaseolina & 10.3 \\
\hline Fusarium graminearum & 8 \\
\hline Rhizoctonia solani & 7 \\
\hline Aspergillus niger & 5.8 \\
\hline Trichophyton mentagrophytes & 6.5 \\
\hline Candida albicans & 0 \\
\hline
\end{tabular}

Table (2) : Crude extract effect of T.harzianum on different pathogenic bacteria

\begin{tabular}{|c|c|}
\hline Test bacteria & $\begin{array}{c}\text { Crude extract inhibition zone on } \\
\text { test bacteria (mm.) }\end{array}$ \\
\hline Staphylococcus aureus & 6 \\
\hline Bacillus subtilis & 7 \\
\hline Streptococcus pyogens & 3 \\
\hline Klebsiella pneumonia & 5 \\
\hline Pseudomonas aeruoginosa & 0 \\
\hline E.coli & 8 \\
\hline Salmonella typhimurium & 4 \\
\hline
\end{tabular}




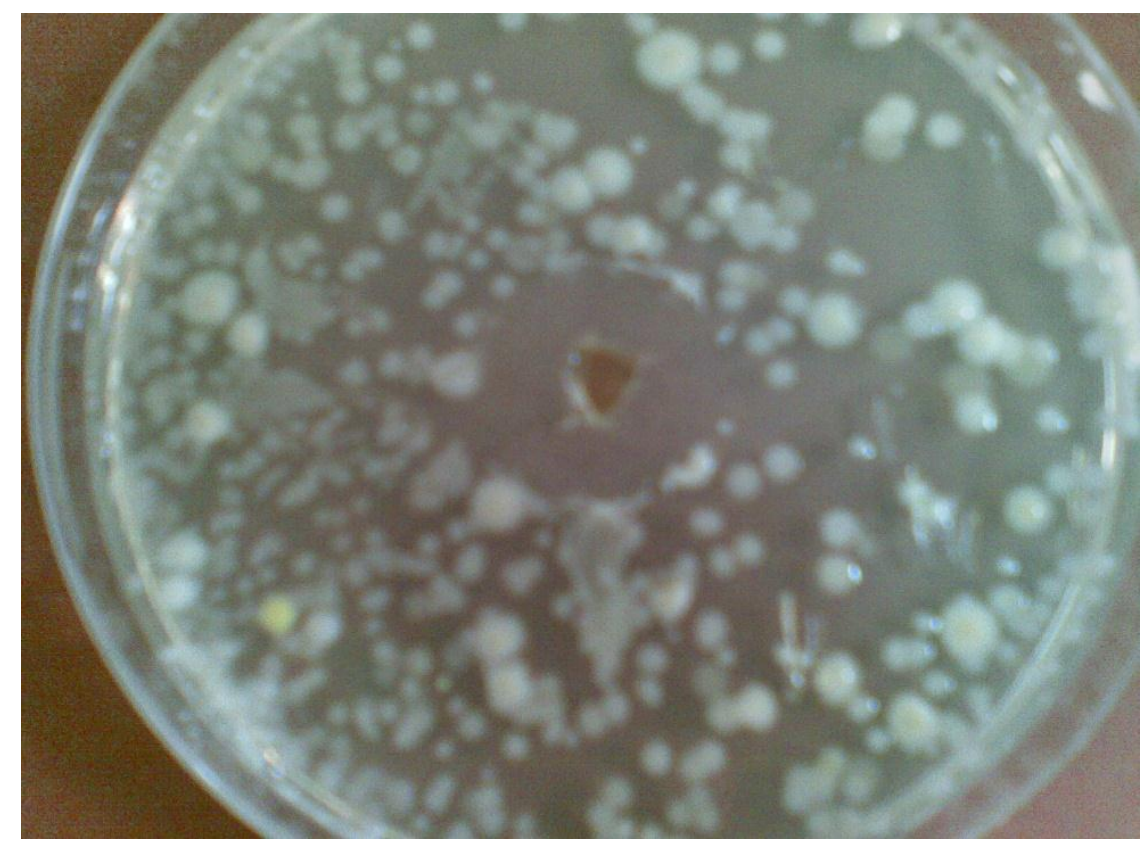

Figure (2) : Antibacterial activity of T.harzianum crude extract against Bacillus spp.

It was noticed from table ( 1 and 2 ) that the crude extract of the fungus T.harzianum showed a wide and different range of antifungal activities against different types of plant and human pathogenic fungi, also against different types of Gram positive and negative human pathogenic bacteria, and we recommend further studies to test the antimicrobial activity of the T. harzianum and its extract against other different fungal and bacterial pathogens, and to characterize the nature of the antimicrobial compound (whether it is protein or not) using different analytical methods such as mass spectrophotometry, gas chromatography (GC) , HPLC, FTIR, etc.. for industrially and commercially production of this antimicrobial compound that could represent a potent alternative to the artificially chemical antimicrobial products that have side effects.

\section{REFERENCES}

1. Barak R.; Elad Y.; Mirelman D. ; and Chet I. , Phytopathology 75, 458 (1985).

2. Chet I., in: Chet I. (ed.) Innovative approaches to plant disease control, Wiley, New York, pp 137-160 (1987).

3. Howell C.R., Plant Disease 87(4) (2003).

4. Harman G.E.; Howell C.R.; Viterbo A.; Chet I.; and Lorito M., Nature Rev. Microbiology. 2 (43) (2004).

5. Whitmore L. and Wallace B.A., Nucleic Acids Res. 1 (32) (Database issue): D593-594 (2004). 
6. Degenkolb T.; Gräfenhahn T.; Nirenberg H.I.; Gams W.; and Brückner H. J. Agric. Food Chem. 54, 7074 (2006).

7. Engelberth J.; Koch T.; Schuler G.; Bachmann N.; Rechtenbach J.; and Boland W. Plant Physiol. 125(1): 369(2001).

8. Benitez T.; Rincon A.M.; Limon M.C.; and Codon A.C. Int. Microbiol. 7(4): 249-260 (2004).

9. Kucuk C.; and Kivanc M. In Vitro antifungal activity of strains of Trichoderma harzianum. Turkish Journal of Biology 28: 111- 115 (2004).

10.Marfori E. C.; Kajiyama S.; Fukusaki E.; and Kobayashi A. Trichsetin, anovel tetramic acid antibiotic produced in dual culture of Trichoderma harzianum and Catharanthus roseus callus Z.Naturforsch. 57c: 465-470 (2002).

11.Rebuffat S.; Pringent Y.; Auvin.Guette Y.C.; and Bodo B., Eur. J. Biochem. 201, 661 (1991).

12.Landreau A.; Pouchus Y.F.; Sallenave C.; Biard J.F.; Boumard M.C.; Pont T.R.; Mondeguer F.; Goulard C.; and Verbist J.F. J. Microbiol. Methods 48, 181 (2002).

13.Gupta C. P.; Dubey R. C.; Kang S. C.; and Maheshwari D. K. Antibiosis-mediated necrotrophic effect of Pseudomonas GRC2 against two fungal plant pathogens. Current Science. 81(1): 91-94 (2001).

14.Eziashi E. I.; Omamor B.; and Odigie E. E. Antagonism of Trichoderma viride and effects of extracted water soluble compounds from Trichoderma species and benlate solution on Ceratocystis paradoxa. African Journal of Biotechnology. 6(4), pp.388-392, (2007).

15.Bissett, J., A revision of the genus Trichoderma.I. Section Longibrachiatum sect. Nov. Can. J. Bot. 62: 924-931 (1984).

16.Oh S.U.; Yun B.S.; Lee S.J.; Kim J.H.; and Yoo I.D., J. Antibiot. 55, 557 (2002).

17.Szekeres A.; Leitgeb B.; Kredics L.; Antal Z.; Hatvani L.; Manczinger L.; and Vagvöglyi Cs., Acta Microbiol.et Immunol. hungarica 52. 137 (2005).

18.Zeilinger S.; Reithner B.; Scala V.; Peissl I.; Lorito M.; and Mach R.L. Applied and Environmental Microbiology, 71 (3), 1591 (2005).

19.Brückner H.; Kirschbaum J.; and Jaworski A. Proceedings of the 27th European Peptide Symposium,Sorrento, Etizioni Ziino, Napoli, Italy, (2002). 